\title{
Editorial
}

\section{Resilient Flood Defenses}

\author{
Suzanne J.M.H. Hulscher ${ }^{1, * \mathbb{D}}$, Jord J. Warmink ${ }^{1} \mathbb{D}$ and Bas W. Borsje ${ }^{2}$ \\ 1 Department of Marine and Fluvial Systems, University of Twente, Drienerlolaan 5, \\ 7522 NB Enschede, The Netherlands; j.j.warmink@utwente.nl \\ 2 Water Engineering\&management, University of Twente, P.O. Box 217, 7500 AE Enschede, The Netherlands; \\ b.w.borsje@utwente.nl \\ * Correspondence: s.j.m.h.hulscher@utwente.nl
}

Citation: Hulscher, S.J.M.H.; Warmink, J.J.; Borsje, B.W. Resilient Flood Defenses. J. Mar. Sci. Eng. 2021, 9, 371. https://doi.org/10.3390 /jmse9040371

Received: 15 March 2021

Accepted: 22 March 2021

Published: 31 March 2021

Publisher's Note: MDPI stays neutral with regard to jurisdictional claims in published maps and institutional affiliations.

Copyright: (c) 2021 by the authors. Licensee MDPI, Basel, Switzerland. This article is an open access article distributed under the terms and conditions of the Creative Commons Attribution (CC BY) license (https:/ / creativecommons.org/licenses/by/ $4.0 /)$.
Flood risk in deltaic regions is increasing due to a combination of more economic activities and an increase in flooding probability. These flood threats are expected to increase even further in the future, due to sea-level rise, changes in storm climate as well as more extreme river discharges. Therefore, protection against flooding, i.e., flood safety, is becoming increasingly important all over the world.

Traditionally, hard structures are used as flood protection measures. These structures are static and do not respond to changing boundary conditions, such as sea-level rise, more extreme discharges, and increasing storminess. Moreover, the energy released during extreme events is hardly dissipated, resulting in potentially enormous losses and damage. Therefore, innovative and sustainable solutions for flood defenses, both technical and societal, are called upon. At the moment, we are just starting to explore such new concepts such as so-called soft solutions such as nature-based solutions, and we need technical and bio- and geophysical knowledge that helps us in the design of such new flood protection concepts. The concepts that are able to recover and adapt to future needs and threats do we call resilient flood defenses. These resilient flood defenses potentially allow for further economic growth in coastal and deltaic regions and they are attractive to explore. However, in many cases, we will need to look for smart combinations of the traditionally hard structures with the new flood safety concepts to guarantee safety and economic activity. Herein, the multifunctional dikes, i.e., dikes that have more user functions than flood safely only, come into play. Such dikes with e.g., a bicycle path or road along the dike, commonly are non-uniform across the dike which affects safety. These situations and concepts are largely unexplored at the moment.

In this special issue, we present contributions that focus on process-based understanding of flood defense systems, as well as the effectiveness of flood risk reduction due to hard structures. In particular, we present papers that link to nature-based solutions and to the stability of nonuniform dikes. We expect that these contributions will help in future designs of resilient flood defenses, as well as the maintenance of such concepts under climate changes. The eight papers in this special issue address the knowledge gap towards resilient flood defenses.

The paper contributions in this special issue can be subdivided into the following two subjects: Processes related to resilient flood defenses and Stability of multifunctional dikes. These are described in more detail in the following two subsections.

Resilient flood defenses are an innovative way to protect our coast. However, processbased understanding of the fundamental bio-physical processes related to resilient flood defenses is scarce and thereby hampers the implementation of the concept. Observation data are an essential starting point to understand the resilience of a certain system. Winters et al. [1] adopted unmanned aerial vehicle (UAV) surveys to observe construction and evolution of a novel hybrid nature-based dune structure. These data were needed to understand the physical dynamics of complex hybrid dunes and expected resilience conferred by various design elements. This innovative method and the related data will help us to design future hybrid structures and their assessment. 
Moreover, important to acknowledge in studying processes related to resilient flood defense systems are the large spatial and temporal scales involved. Galiforni-Silva et al. [2] showed that it is essential to take shoal attachment processes, which act on a large spatial scale, into consideration to explain dune development. Next, Bennett et al. [3], pointed out the importance of understanding the effects of localized anthropogenic coastal management interventions on the large spatial scale (the entire estuarine system). Considering large temporal scales, Siemes et al. [4] showed that, in order to stimulate saltmarsh development, first the long-term autonomous development needs to be studied Based on historic data, it turned out that the disintegration of artificial structures has led to the strong retreat of the saltmarshes. Next, based on model results it turned out that traditional structures, which were widely implemented in the past, proved to be most effective to stimulate marsh growth. Additionally, the recognition of the large temporal scale on which sea level rises acts was key to understand the resilience of flood defense systems as studied by Marijnissen et al. [5]. At a low sea-level rise rate, the marshes can accrete such that dike heightening is partially mitigated. But with sea-level rise accelerating, a threshold is reached where dike heightening needs to compensate in case of future loss of marshes, and for future increasing water levels.

Flood defenses around the world are often constructed with a cover layer of hard, inflexible revetment materials, such as rocks and high-quality clay, which typically needs to be transported from elsewhere. These hard revetments are costly and difficult to modify and maintain over the long-term, under changing climate conditions. Therefore, there is an increasing interest to replace these hard materials, where possible, with cheaper and more sustainable soft materials such as sand or clay locally mined. Additionally, the wave load reducing salt marshes in front of the dike are increasingly included in the analysis of dike stability, leading to a variety of multifunctional dikes.

Most multifunctional dikes are hybrid structures that combine hard elements such as breakwaters [6], rock revetments [7] or rip-rap [1] and soft material such as sand [1,2], clay on the dike [5,8], or sandy and clayey soils as salt marshes in front of the dike [3,4]. Hard dike covers are often applied in cases of extreme wave loads, but they are also used as a practical solution because the fundamental understanding of the strength of dike covers based on vegetated soil is missing. The locations at which hard and soft dike cover materials connect are called transitions. Multifunctional dikes typically have many transitions, which are well known to be weak spots that threaten the stability of multifunctional dikes. Only a few experimental and numerical models are able to simulate the detailed flow processes and turbulence necessary to accurately simulate the hydraulic loads at these transitions. Numerical modeling is increasingly used to enhance the understanding of the detailed hydrodynamics and turbulence at the water-structure interface. Especially at the transitions, the hydrodynamics are challenging.

Pourteimouri and Hejazi [1] developed a numerical model to investigate the wave interactions with permeable submerged breakwaters. They were able to explicitly model the fluid-porous medium interaction, thereby increasing the understanding of wave dissipation at permeable flood defense structures. Permeable rock armor revetments are typically used as a hard solution on the waterside slope of dikes to dissipate wave energy to reduce wave overtopping [7]. Based on experiments in a laboratory wave tank, Chen et al. [7] showed that rock armor applied in the wave run-up zone on the upper slope is most effective in reducing wave overtopping. They show that the newly developed analytical equations developed by Chen et al. [9] are also valid for rock armor under specific conditions.

The paper by Van Bergeijk et al. [8] presents a new numerical model to simulate wave overtopping flow over multifunctional dikes. This model proved to be able to quantify the small-scale hydraulic forces that occur at transitions in grass-covered flood defenses.

This special issue presents 8 contributions related to resilient flood defenses. It addresses physical, biological, and computational challenges which will contribute to the knowledge that will help in the design of the innovative concepts. Next, also new insights related to the stability of non-uniform dikes are presented, both at the land as well as the 
seaside as well as underwater. Such knowledge is increasingly called for as dikes usually have multiple functions as e.g., a road along the dike. We expect that smart combinations of hard and soft structures will give the best solutions for future flood protection.

Author Contributions: S.J.M.H.H., J.J.W. and B.W.B. jointly developed the concept and co-wrote this editorial. All authors have read and agreed to the published version of the manuscript.

Acknowledgments: The authors wish to thank all contributors to this Special Issue. The authors also wish to thank the very professional and efficient JMSE editorial staff without whose excellent assistance this issue would not have been possible. Additionally, the authors thank Dorette Olthof and Anke Wigger for their assistance in general and the help in editing this editorial paper in particular.

Conflicts of Interest: The authors declare no conflict of interest.

\section{References}

1. Winters, M.A.; Leslie, B.; Sloane, E.B.; Gallien, T.W. Observations and Preliminary Vulnerability Assessment of a Hybrid Dune-Based Living Shoreline. J. Mar. Sci. Eng. 2020, 8, 920. [CrossRef]

2. Galiforni-Silva, F.; Wijnberg, K.M.; Hulscher, S.J.M.H. On the Relation between Beach-Dune Dynamics and Shoal Attachment Processes: A Case Study in Terschelling (NL). J. Mar. Sci. Eng. 2020, 8, 541. [CrossRef]

3. Bennett, W.G.; van Veelen, T.J.; Fairchild, T.P.; Griffin, J.N.; Karunarathna, H. Computational Modelling of the Impacts of Saltmarsh Management Interventions on Hydrodynamics of a Small Macro-Tidal Estuary. J. Mar. Sci. Eng. 2020, 8, 373. [CrossRef]

4. Siemes, R.W.A.; Borsje, B.W.; Daggenvoorde, R.J.; Hulscher, S.J.M.H. Artificial Structures Steer Morphological Development of Salt Marshes: A Model Study. J. Mar. Sci. Eng. 2020, 8, 326. [CrossRef]

5. Marijnissen, R.; Kok, M.; Kroeze, C.; van Loon-Steensma, J. The Sensitivity of a Dike-Marsh System to Sea-Level Rise-A Model-Based Exploration. J. Mar. Sci. Eng. 2020, 8, 42. [CrossRef]

6. Pourteimouri, P.; Hejazi, K. Development of An Integrated Numerical Model for Simulating Wave Interaction with Permeable Submerged Breakwaters Using Extended Navier-Stokes Equations. J. Mar. Sci. Eng. 2020, 8, 87. [CrossRef]

7. Chen, W.; Marconi, A.; van Gent, M.R.; Warmink, J.J;; Hulscher, S.J. Experimental Study on the Influence of Berms and Roughness on Wave Overtopping at Rock-Armoured Dikes. J. Mar. Sci. Eng. 2020, 8, 446. [CrossRef]

8. van Bergeijk, V.M.; Warmink, J.J; Hulscher, S.J.M.H. Modelling the Wave Overtopping Flow over the Crest and the Landward Slope of Grass-Covered Flood Defences. J. Mar. Sci. Eng. 2020, 8, 489. [CrossRef]

9. Chen, W.; van Gent, M.R.A.; Warmink, J.J.; Hulscher, S.J.M.H. The influence of a berm and roughness on the wave overtopping at dikes. Coastal Eng. 2020, 156, 103613. [CrossRef] 